\title{
The Midwifery Traditional Method
}

\author{
Paola Agnese Mauri ${ }^{1,2 *}$ and Norma Nilde Guerrini Contini ${ }^{2}$ \\ ${ }^{1}$ Department of Clinical Sciences and Community Health, Università degli Studi di Milano, Italy \\ ${ }^{2}$ Unit of Mother Child and Newborn Health, Fondazione IRCCS Ca' Granda Ospedale Maggiore Policlinico, Italy
}

Submission: January 19, 2018; Published: January 24, 2018

*Corresponding author: Paola Agnese Mauri, Department of Clinical Sciences and Community Health, Università degli Studi di Milano, School of Midwifery, Unit of mother child and newborn health, Fondazione IRCCS Ca' Granda Ospedale Maggiore Policlinico, Milan, Italy, Tel: +39 0255038599; Email: paola.mauri@unimi.it

\section{Opinion}

We are committed in training in an Italian Midwifery School and we think is fundamental to rediscover a training method which can develop diagnostic and assistance skills for health professionals, including those still in training. Attending a vaginal breech birth can be challenging if the obstetrician or the midwife has no experience [1], and can be dangerous if he/she does not make an appropriate diagnosis with a rigorous method. We think a good method allowing to making diagnosis and assistance is the "traditional" [2]. It is made up of seven steps in progressive order: anamnesis; inspection; palpation; auscultation; exploration; first level diagnostics (basic obstetrical ultrasound) and, if necessary, second level diagnostics (advanced obstetrical ultrasound).

In the labour ward we work (approximately 6000 deliveries each year) we rarely see staff observe all six/seven steps of the "midwifery traditional method".

First step: Anamnesis [2]. Health professionals very often do not even make women questions as: "where do you most feel your baby's kicks?" Midwives have forgotten that anamnesis is critical to diagnosis.

Second step: Inspection [2]. We see staff does not watch the shape of maternal abdomen.

Third step: Palpation [2]. We also see they do not always use Leopold's manoeuvres and rarely, if fetus is cephalic, consider Lorier, Favre/Pinarde Crichton signs [2].

Fourth step: Auscultation [2]. Midwives often apply monitors mechanically without considering the link between fetal hearth frequency, its most intense outbreak, fetal presentation and fetal position.

Fifth step: Exploration [2]. A vaginal examination should take into consideration characteristics of external genitalia, vagina, cervix, state of membranes, and also organoleptic characteristics of amniotic fluid (when appreciable), fetal presentation and fetal position, level of engagement of the presenting part. Diagnosis of engagement of the presenting part must be done through the contact of the pubic symphysis and Farabeuf [2,3] and Demielin signs [2]. Furthermore health professionals should always observe characteristics of uterine contractions, maternal perceived pain (through analog scales as the NRS), woman's mood (collaborative, not collaborative, brave, demoralized etc.), fetal heart rate and fetal movements. Finally a vaginal examination should be ended writing clinical records including date, hour and signature of the performer.

Sixth step: first level diagnostics (basic obstetrical ultrasound) [2]. We see too many times obstetricians and midwives using ultrasounds as first step of an obstetric examination, when it should be the last one so that it becomes a cool tool for a hasty diagnosis.

"Midwifery traditional method" is the only one which supports clinical certainty and that can introduce to a hand on care. Kind Editor, we think it is fundamental help obstetricians and midwives to develop competencies for birth and encourage to make use of the precious cultural baggage which is the obstetric semeiotic.

\section{References}

1. Walker S, Breslin E, Scamell M, Parker P (2017) Effectiveness of vaginal breech birth training strategies: An integrative review of the literature. Birth 44(2): 101-109.

2. Costantini W, Calistri D (2013) Midwife. Piccin, Padua.

3. Gernez L (1981) The engaged or non-engaged head: reconsideration of Farabeuf's sign. J Gynecol Obstet Biol Reprod 10(4): 365-358. 
This work is licensed under Creative Commons Attribution 4.0 Licens DOI: 10.19080/OAJS.2018.07.555718

\section{Your next submission with Juniper Publishers will reach you the below assets}

- Quality Editorial service

- Swift Peer Review

- Reprints availability

- E-prints Service

- Manuscript Podcast for convenient understanding

- Global attainment for your research

- Manuscript accessibility in different formats

( Pdf, E-pub, Full Text, Audio)

- Unceasing customer service

Track the below URL for one-step submission https://juniperpublishers.com/online-submission.php 